\title{
Improved survival of patients with homozygous familial hypercholesterolaemia treated with plasma exchange
}

\author{
G R THOMPSON, J P MILLER, J L BRESLOW
}

\begin{abstract}
Plasma exchange was undertaken in five patients with homozygous familial hypercholesterolaemia at intervals of two weeks for a mean of 8.4 years. These patients had survived an average of 5.5 years longer than their five respective homozygous siblings ( $p$ $=0.03$ ), each of whom must have had a matching genetic defect but who died untreated. The $37 \%$ decrease in peak serum cholesterol concentrations maintained by plasma exchange presumably reduced progression of atherosclerosis in the treated patients and thus lessened their risk of premature death.
\end{abstract}

\section{Introduction}

The use of plasma exchange to treat homozygous familial hypercholesterolaemia was first introduced 10 years ago.' Familial hypercholesterolaemia can be caused by any one of the seven described mutations of the gene for the low density lipoprotein receptor ${ }^{2}$ that has recently been cloned. ${ }^{3}$ Inheritance of identical or dissimilar mutant alleles from each parent gives rise to the homozygous form of the disease, which is characterised by a considerable increase in low density lipoprotein cholesterol concentration from birth, appearance of cutaneotendinous xanthomas and onset of aortocoronary atherosclerosis in childhood, and a liability to sudden death in early adult life. ${ }^{4}$

Familial hypercholesterolaemia is notoriously resistant to treatment with diet and drugs, although receptor defective homo-

Medical Research Council Lipoprotein Team, Hammersmith Hospital, London W12

G R THOMPSON, MD, FRCP, consultant physician

Department of Medicine, University Hospital of South Manchester, West Didsbury, Manchester

J P MILLER, DPHIL, FRCP, consultant gastroenterologist

Department of Biochemical Genetics and Metabolism, The Rockefeller University, New York, United States of America

J L BRESLOW, MD, professor

Correspondence to: Dr Thompson. zygotes, who have detectable low density lipoprotein receptor activities, respond better than receptor negative homozygotes, in whom such activities are absent. ${ }^{45}$ These differences reflect the nature of the underlying mutation and result in considerable variability between homozygotes with respect to the speed of onset of cardiovascular complications ${ }^{6}$ and age at death. ${ }^{4}$ This paper reports the beneficial effects of plasma exchange on the survival of five homozygotes treated after 1975, each of whom had a homozygous sibling, with a presumed identical defect of low density lipoprotein receptor, who died without undergoing this treatment.

\section{Subjects and methods}

All five patients have been described in detail previously. ${ }^{7.9}$ Two (cases 1 and 2) were treated after 1975-6 at Hammersmith Hospital, London; one (case 3) was treated in London 1978-80 but afterwards at the Manchester Royal Infirmary; and two (cases 4 and 5) were treated from 1976 onwards at the Children's Hospital, Boston. Plasma exchange was performed roughly every two weeks on an outpatient basis using an Aminco or IBM continuous flow cell separator, with $2 \cdot 5-51$ plasma protein fraction as the exchange medium and heparin as the anticoagulant. ' Serum cholesterol and triglyceride concentrations were measured immediately before each plasma exchange, either by colorimetric methods ${ }^{7.9}$ or latterly by enzymatic analysis (Technicon autoanalyser methods No SE4-0065 FBI and SE4-0039 PE6). High density lipoprotein cholesterol concentration was measured similarly, after heparin-manganese precipitation. ${ }^{10}$ Low density lipoprotein receptor state was determined in cultured skin fibroblasts. ${ }^{11}$

Details of each patient's age, biochemical state, and duration of plasma exchange are given below, but additional information is as follows: an Englishman (case 1) died in 1984 after a failed aortic valve replacement procedure. In addition to plasma exchange, he had received nicotinic acid 5 $\mathrm{g} /$ day and, latterly, mevinolin $80 \mathrm{mg} /$ day. Another Englishman (case 2) also received nicotinic acid and, more recently, mevinolin $80 \mathrm{mg} /$ day. $\mathrm{He}$ underwent prophylactic coronary artery bypass grafting in 1983 and remained asymptomatic. An Asian man (case 3) lived in Britain but went home to Zambia for two months each year, during which time he did not undergo plasma exchange. He recently underwent prophylactic coronary artery bypass grafting for his angiographically documented but asymptomatic coronary ostial stenosis. An American man (case 4) underwent partial ileal bypass aged $17,{ }^{9}$ which was reversed one year later due to gastrointestinal side effects. An American woman (case 5) underwent total biliary diversion aged 6 without benefit'; biliary continuity was restored 21 months later. The four living patients remained well and continued treatment with plasma exchange. 


\section{Results}

Table 1 shows the low density lipoprotein receptor state and basal serum lipid concentrations in the five homozygotes who underwent plasma exchange. One patient (case 5) was receptor negative, the four others receptor defective. All had severe hypercholesterolaemia, which, in the presence of normal triglyceride and subnormal high density lipoprotein cholesterol concentrations, can be calculated as being due to roughly fourfold increase in low density lipoprotein cholesterol concentrations. ${ }^{12}$

Table II shows details of the age and sex of these patients and their homozygous siblings, together with the duration and cholesterol lowering effect of plasma exchange. This procedure has been performed for the past nine years in four patients and for six years in the remaining patient (case 3).

TABLE I-Low density lipoprotein receptor state and serum lipid concentrations (mmol/l) before treatment in five homozygotes with familial hypercholesterolaemia

\begin{tabular}{lcccc}
\hline Case No & $\begin{array}{c}\text { Receptor } \\
\text { state }\end{array}$ & $\begin{array}{c}\text { Serum } \\
\text { cholesterol }\end{array}$ & $\begin{array}{c}\text { Triglyceride } \\
\text { High density } \\
\text { lipoprotein } \\
\text { cholesterol }\end{array}$ \\
\hline 1 & Defective & $19 \cdot 6$ & 0.90 & $0 \cdot 72$ \\
2 & Defective & $19 \cdot 8$ & $1 \cdot 10$ & 0.65 \\
3 & Defective & $18 \cdot 0$ & 0.90 & $0 \cdot 85$ \\
4 & Defective & $19 \cdot 0$ & $2 \cdot 71$ & 0.67 \\
5 & Negative & 17.9 & 0.73 & $0 \cdot 72$ \\
\hline
\end{tabular}

Conversion: SI to traditional units - Cholesterol: $1 \mathrm{mmol} / 1 \approx 38.6$ $\mathrm{mg} / 100 \mathrm{ml}$. Triglyceride: $1 \mathrm{mmol} / \mathrm{l} \approx 88.5 \mathrm{mg} / 100 \mathrm{ml}$. between fortnightly exchanges. ${ }^{17}$ As a result total and low density lipoprotein cholesterol concentrations in homozygotes undergoing this treatment are similar to those found in untreated heterozygotes with familial hypercholesterolaemia.

The defect of low density lipoprotein receptor responsible for familial hypercholesterolaemia was first identified in 1973 by Goldstein and Brown, ${ }^{23}$ and they and their colleagues have subsequently investigated in detail the structure and function of the low density lipoprotein receptor and its gene. ${ }^{3}$ Their findings indicate that several different mutations exist, any one of which can give rise to the phenotype of familial hypercholesterolaemia. Biochemical expression of the disorder depends on the nature of the underlying mutation. Fibroblasts from receptor negative homozygotes, for example, express virtually no detectable low density lipoprotein receptor activity, whereas receptor defective homozygotes can express $25-30 \%$ of the activity seen in normal fibroblasts. ${ }^{45}$ Receptor negative homozygotes seem to have mutations that prevent synthesis or maturation of the low density lipoprotein receptor. ${ }^{2}$ Clinical severity, judged by degree of hypercholesterolaemia, earliness of onset of cardiovascular complications, unresponsiveness to treatment with drugs, and liability to premature death, is also more noticeable in receptor negative than in receptor defective homozygotes. ${ }^{4-624}$

The variability of expression of homozygous familial hypercholesterolaemia resulting from genetic heterogeneity can be overcome by using pairs of siblings as, by definition, each homozygous

TABLE II-Ages of homozygotes with familial hypercholesterolaemia undergoing plasma exchange and of their untreated homozygous siblings

\begin{tabular}{|c|c|c|c|c|c|}
\hline \multirow[b]{2}{*}{ Case No } & \multirow[b]{2}{*}{ Sex } & \multirow[b]{2}{*}{$\begin{array}{c}\text { Age } \\
\text { (years) }\end{array}$} & \multicolumn{2}{|c|}{ Plasma exchange } & \multirow[b]{2}{*}{$\begin{array}{l}\text { Age when treatment } \\
\text { began (years) }\end{array}$} \\
\hline & & & Duration (years) & $\begin{array}{l}\text { Mean (SD) cholesterol } \\
\text { pre-exchange }(\mathrm{mmol} / \mathrm{l})\end{array}$ & \\
\hline 1 & $\mathbf{M}$ & $31 \cdot 7^{\star}$ & 9 & $11.5(1.0)$ & 22 \\
\hline Sibling & $\mathrm{F}$ & $19 \cdot 4^{\star}$ & & & \\
\hline 2 & $M$ & $22 \cdot 0$ & 9 & $12 \cdot 2(1 \cdot 7)$ & 13 \\
\hline Sibling & $M$ & $17 \cdot 2^{\star}$ & & & \\
\hline 3 & M & $21 \cdot 0$ & 6 & $11 \cdot 8(1 \cdot 8)$ & 14 \\
\hline Sibling & M & $23 \cdot 3^{\star}$ & & & \\
\hline 4 & $M$ & $22 \cdot 8$ & 9 & $11 \cdot 6(1 \cdot 0)$ & 14 \\
\hline Sibling & $M$ & $14 \cdot 5^{\star}$ & & & \\
\hline 5 & $\mathrm{~F}$ & $18 \cdot 5$ & 9 & $11.9(1.0)$ & 9 \\
\hline Sibling & $M$ & $13 \cdot 9 \star$ & & & \\
\hline
\end{tabular}

^Deceased.

Conversion: SI to traditional units-Cholesterol: $1 \mathrm{mmol} / \mathrm{l} \approx 38.6 \mathrm{mg} / 100 \mathrm{ml}$

Reduction in serum cholesterol concentrations ranged from $34-41 \%$, being least in the receptor negative patient (case 5).

Table II also shows the age of death of the untreated homozygotes and age at which plasma exchange was begun in their siblings. Three sibling pairs were all male, two were mixed. All but one of the treated patients are still alive, and he (case 1) died postoperatively, whereas all their untreated homozygous siblings are deceased. In each instance death of siblings was sudden and due to atherosclerosis, as described previously.$^{89}$ All but one of the treated patients survived longer than their respective siblings, the mean difference in life span being $5 \cdot 5$ years. Application of the paired log rank test shows that this difference is significant (one tailed, $p=0 \cdot 03$ ). ${ }^{13}$

\section{Discussion}

Plasma exchange has been used to treat homozygous familial hypercholesterolaemia in several centres during the past 10 years. ${ }^{19^{14-16}}$ The safety and beneficial effects of this procedure in 13 such patients were reviewed four years ago, ${ }^{17}$ and thereafter further reports have appeared. ${ }^{18-20}$ Regression of cutaneous and tendinous xanthomas is well documented, and there is evidence that this is usually, ${ }^{121}$ but not always, ${ }^{22}$ accompanied by a reduced rate of progression of aortocoronary lesions. Serum cholesterol concentrations measured immediately before plasma exchange, when they are at their highest, are $40 \%$ lower than with conventional treatment, which represents a $50 \%$ reduction in the mean plasma concentration sibling is bound to have inherited the same pair of mutant alleles from their heterozygous parents. Measurement of low density lipoprotein receptor activity in siblings confirms the validity of this assumption. ${ }^{5}$ Differences of sex seem less important in determining the onset of cardiovascular complications in homozygotes ${ }^{25}$ than in heterozygotes, ${ }^{26-28}$ and receptor state seems to be the overriding factor. High density lipoprotein cholesterol concentrations were subnormal in all five homozygotes before plasma exchange was initiated, which is common. ${ }^{4}$ Four of the five patients underwent surgical procedures, but probably none of these was operative for long enough to have influenced prognosis.

Although the numbers were small, the duration of treatment was sufficiently long to show that plasma exchange signficantly improves life expectancy in homozygous familial hypercholesterolaemia. The beneficial effect of this procedure may have been enhanced by concomitant administration of lipid lowering drugs, notably nicotinic acid and more recently mevinolin. ${ }^{29}$ The latter in a dose of $80 \mathrm{mg} /$ day resulted in a further $11.5 \%$ reduction in serum cholesterol concentration before exchange compared with that in plasma exchange alone (unpublished data). The net result was a halving of low density lipoprotein cholesterol concentrations, which presumably was the chief reason for the clinical improvement and stabilisation of atherosclerotic lesions documented previously. ${ }^{\text {? }}$

Plasma exchange also reduces plasma fibrinogen concentrations, platelet counts, and high density lipoprotein cholesterol concentra- 
tions, but these all return to normal within a week, ${ }^{130}$ whereas low density lipoprotein cholesterol concentrations rise again more slowly. Whether procedures designed to selectively remove low density lipoprotein but conserve high density lipoprotein and other proteins will prove to be as or more effective than plasma exchange remains to be shown. ${ }^{31-33}$ Transplantation of the liver provides the most definitive approach to treatment currently available but necessitates long term immunosuppression, with its attendant drawbacks. ${ }^{34}{ }^{35}$ We conclude that plasma exchange every two weeks offers a safe and proved means of improving prognosis in homozygous familial hypercholesterolaemia with which all newer forms of treatment can be compared.

We thank all our colleagues, both doctors and nurses, whose skill and stamina have enabled well over 1000 plasma exchanges to be undertaken over the past 10 years without mishap, Drs J Goldstein and M Brown for measuring the low density lipoprotein receptor state of fibroblasts from the three patients treated in Britain, and Dr R Peto and Mr D Robinson for undertaking the statistical analysis.

\section{References}

1 Thompson GR, Lowenthal R, Myant NB. Plasma exchange in the management of homozygous familial hypercholesterolaemia. Lancet 1975; ; 1208-11.

2 Tolleshaug H, Hobgood KK, Brown MS, Goldstein JL. The LDL receptor locus in familial hypercholesterolemia: multiple mutations disrupt transport and processing of a membrane receptor. Cell 1983;32:941-5

3 Yamamoto T, Davis CG, Brown MS, et al. The human LDL receptor: a cysteine-rich protein with multiple Aln sequences in its mRNA. Cell 1984;39:27-38.

4 Goldstein JL, Brown MS. Familial hypercholesterolemia. In: Stanbury JB, Wyngaarden JB, Fredrickson DS, Goldstein JL, Brown MS, eds. The metabolic basis of inherited disease. 5th ed. New York: McGraw Hill, 1983:672-712.

5 Sprecher DL, Hoeg JM, Schaefer EJ, et al. The association of LDL receptor activity, LDL cholesterol level, and clinical course in homozygous familial hypercholesterolemia. Metabolism 1985;34:294-9.

6 Sprecher D, Schaefer EJ, Kent KM, et al. Cardiovascular features of homozygous familial hypercholesterolemia: analysis of 16 patients. Am $\mathcal{F}$ Cardiol 1984;54:20-30.

7 Thompson GR, Myant NB, Kilpatrick D, et al. Assessment of long-term plasma exchange for familial hypercholesterolaemia. Br Heart 7 1980;43:680-8

8 Allen JM, Thompson GR, Myant NB, et al. Cardiovascular complications of homozygous familial hypercholesterolaemia. Br Heart f 1980;44:361-8.

9 King MEE, Breslow JL, Lees RS. Plasma exchange therapy of homozygous familial hypercholesterolemia. N Engl f Med 1980;302:1457-9.

10 Warnick GR, Albers JJ. A comprehensive evaluation of the heparin-manganese precipitation procedure for estimating high density lipoprotein cholesterol. F Lipid Res 1978;19:65-76.

11 Goldstein JL, Dana SE, Brunschede GY, Brown MS. Genetic heterogeneity in familial hypercholesterolemia: evidence for two different mutations affecting functions of low-density lipoprotein receptor. Proc Natl Acad Sci USA 1975;72:1092-6.
12 Friedewald WT, Levy RI, Fredrickson DS. Estimation of the concentration of low-density lipoprotein cholesterol in plasma, without use of the preparative ultracentrifuge. Clin Chem 1972;18:499-502.

13 Peto R, Pike MC, Armitage P, et al. Design and analysis of randomised clinical trials requiring prolonged observation of each patient. II. Analysis and examples. Br f Cancer 1977;35:1-39.

14 Berger GMB, Miller JL, Bonnici F, et al. Continuous flow plasma exchange in the treatment of homozygous familial hypercholesterolemia. Am $\mathcal{F}$ Med 1978;65:243-51

15 Witzum JL, Williams JC, Ostlund R, et al. Successful plasmapheresis in a 4 year old child with homozygous familial hypercholesterolemia. F Pediatr 1980;97:615-8.

16 Stein EA, Glueck CJ, Wesselman A, et al. Repetitive intermittent flow plasma exchange in patients with severe hypercholesterolemia. Atherosclerosis 1981;38:149-64.

7 Thompson GR. Plasma exchange for hypercholesterolaemia. Lancet $1981 ;$ i: 1246-8.

18 Barr SI, Kottke BA, Pineda AA, Mao SJT. Plasma lipid and apoprotein levels following plasmapheresis in a subject homozygous for familial hypercholesterolemia. Experientia $1981 ; 37: 114-5$

19 Postiglione A, Rubba P, Scarpato N, et al. Increased blood flow to lower limbs after plasma exchange in two patients with familial hypercholesterolemia. Atherosclerosis 1982;41:421-5.

20 Dhondt JL, Farriaux JP, Fruchart JC, Koffigan-Leitao M. Plasmapheresis in type II hypercholesterolaemia. Fournal of Inherited Metabolic Disease 1982;5(suppl 1):6.

21 Berger GMB, Bonnici F, Joffe HS, Dubovsky DW. Plasma exchange in the treatment of familial hypercholesterolemia. In: Gotto AM, Smith LC, Allen B, eds. Atherosclerosis $V$. New York: Springer Verlag, 1980:458-61.

22 Leonard JV, Clark M, Macartney FJ, Slack J. Progression of atheroma in homozygous familial hypercholesterolemia during regular plasma exchange. Lancet 1981;ii:811.

23 Goldstein JL, Brown MS. Familial hypercholesterolemia: identification of a defect in the regulation of 3-hydroxy-3-methylglutaryl coenzyme A reductase activity associated with overproduction of cholesterol. Proc Natl Acad Sci USA 1973;70:2804-8.

24 Breslow JL, Spaulding DR, Lux SE, et al. Homozygous familial hypercholesterolemia. $N$ Engl Med 1975;293:900-3.

25 Seftel HC, Baker SG, Sandler MP, et al. A host of hypercholesterolaemic homozygotes in South Africa. Br Med f 1980;281:633-6.

26 Slack J. Risk of ischaemic heart disease in familial hyperlipoproteinaemic states. Lancel 1969 ;ii: $1380-2$

27 Stone NJ, Levy RI, Fredrickson DS, Verter J. Coronary artery disease in 116 kindred with familial type II hyperlipoproteinemia. Circulation 1974;49:476-88.

28 Gagné C, Moorjani S, Brun D, et al. Heterozygous familial hypercholesterolemia. Relationship between plasma lipids, lipoproteins, clinical manifestations and ischaemic heart disease in men and women. Atherosclerosis 1979;34:13-24.

29 Tobert JA, Bell GD, Birtwell J, et al. Cholesterol-lowering effect of mevinolin, an inhibitor of 3 hydroxy-3-methylglutaryl coenzyme A reductase in healthy volunteers. $\mathcal{F}$ Clin Invest 1982;69: 913-9.

30 Keller AJ, Chirnside A, Urbaniak SJ. Coagulation abnormalities produced by plasma exchange on the cell separator with special reference to fibrinogen and platelet levels. $\mathrm{Br} f \mathrm{Haematol}$ 1979:42:593-603.

31 Lupien PJ, Mooriani S, Awad J. A new approach to the management of familial hypercholesterolaemia: removal of plasma cholesterol based on the principle of affinity chromatography. Lancet 1976;: $1261-5$

32 Stoffel W, Borberg H, Greve V. Application of specific extracorporeal removal of low density lipoprotein in familial hypercholesterolaemia. Lancet 1981;ii: 1005-7.

33 Yokoyama S, Hayashi R, Kikkawa T, et al. Specific sorbent of apolipoprotein B containing lipoproteins for plasmapheresis. Characterisation and experimental use in hypercholesterolemic rabbits. Arteriosclerosis 1984;4:276-82

34 Starzl TE, Bilheimer DW, Bahnson HT, et al. Heart-liver transplantation in a patient with familial hypercholesterolaemia. Lancet 1984 ; i: $1382-3$.

35 Bilheimer DW, Goldstein JL, Grundy SM, et al. Liver transplantation to provide low-densitylipoprotein receptors and lower plasma cholesterol in a child with homozygous familial hypercholesterolemia. N Engl f Med 1984;311:1658-64.

(Accepled 9 October 1985)

\title{
Emphysema, cirrhosis, and heart block in a young patient with partial $\alpha_{1}$ antitrypsin deficiency (PiMZ phenotype)
}

\author{
CHRISTINE F McDONALD, PAUL M STEWART, GILLIAN BLUNDELL, \\ GRAHAM K CROMPTON
}

\begin{abstract}
Severe lung disease and liver disease are not recognised features of the PiMZ phenotype, which is associated with $\alpha_{1}$ antitrypsin deficiency. A 31 year old woman with this phenotype was found to have emphysema and complete heart block and showed evidence
\end{abstract}

Respiratory Diseases Unit, Northern General Hospital, Edinburgh EH5 2DQ CHRISTINE F MCDONALD, MB, FRACP, research assistant

PAUL M STEWART, MB, MRCP, senior house officer

GRAHAM K CROMPTON, MB, FRCPED, consultant physician

Department of Clinical Chemistry, Western General Hospital, Edinburgh EH4 2XU

GILLIAN BLUNDELL, MB, FRCPATH, consultant clinical chemist

Correspondence to: Dr Crompton. of hepatic cirrhosis, although her three sisters, all of whom had the same phenotype, were clinically normal.

This case supports the possibility of a causal relation between the PiMZ phenotype and chronic lung and liver disease, but an association between $\alpha_{1}$ antitrypsin deficiency and complete heart block could not be proved in this patient.

\section{Introduction}

It is not clear whether the $\alpha_{1}$ antitrypsin PiMZ heterozygous state predisposes to lung disease. ${ }^{1-4}$ We report on a patient with the PiMZ phenotype who at the age of 36 had severe emphysema, evidence of hepatic cirrhosis, and complete heart block. Neither severe lung disease nor liver disease is a recognised feature of the PiMZ phenotype, and heart block has not previously been reported in association with partial $\alpha_{1}$ antitrypsin deficiency. 